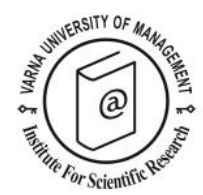

\title{
Degree of political attention towards tourism: An analysis of party manifestos during German federal elections
}

\author{
Ralf Vogler ${ }^{*}$
}

\author{
${ }^{1}$ Department of Tourism, Heilbronn University, Heilbronn, Germany. E-mail: ralf.vogler@hs-heilbronn.de \\ ${ }^{*}$ Corresponding author
}

\begin{abstract}
The attention that political parties pay to the tourism sector's issues has been an underresearched subject for tourism science. This paper aims to fill the gap by analysing political awareness for tourism-related topics on a national level. It will answer the question of whether tourism plays an important role in parties' manifestos and in which context it is addressed. To facilitate the research, the paper applies a quantitative content analysis as well as a contextual analysis. Results show that within parties' manifestos tourism topics are discussed and used for the political debate, not only for their economic aspects but in the context of infrastructure and sustainability as well. It becomes clear that tourism on a national level serves as a vehicle to communicate the general ideological message of the respective political party. The findings of this paper complement earlier studies regarding regional politics and tourism.
\end{abstract}

Keywords: tourism policy; elections; campaign; tourism politics; political parties; governments.

Citation: Vogler, R. (2022). Degree of political attention towards tourism: An analysis of party manifestos during German federal elections. European Journal of Tourism Research 31, 3114. 


\section{Introduction}

Governments, and subsequently political parties, have a genuine interest in the tourism sector. Significant scientific attention is focused on the relationship between tourism and governmental interaction (Jenkins, 2020; Fayos-Sola, 1996). Such an interaction is fuelled by the tourism industry's impact on the general economy as well as labour markets of both source markets and destinations (Hieu \& Yen, 2019, Aslan, 2016; Perles-Ribes et al., 2016). Hence, politicians and governments are required to consider tourism aspects in their governmental work (Elliott, 1997), as the tourism system represents significant employment opportunities (Eurostat, 2021) and GDP contribution (UNWTO, 2018). These tourism aspects have a certain degree of importance, not only for governments and politicians but especially for citizens who are employed in the tourism industry. From a political process perspective, such importance might yield a corresponding voting behaviour during governmental elections. This is particularly true, considering that elections in most countries represent the most important possibility to express interest in changes or continuity of policies (Demirkol et al., 2016).

Considering that economic aspects are a driving force for election success (Franzmann et al., 2020), the political attention of parties should mirror the economic importance of each sector. However, an economic perception does not exist independently from other aspects. In most cases, it is mixed with cultural perceptions. Such a mix is, for example, visible in countries with a perceived strong automotive industry (Mattioli et al., 2020) and can also be assumed for the tourism industry. In particular, countries that serve as destinations with significant touristic activity also possess a cultural tourism heritage.

Taking the above into account, it remains of interest if the political perception and awareness of tourism are distributed fairly considering its share in GDP as well as employment. For this reason, the paper raises the question to what extent political parties, as actors in the political arena, consider the tourism system as an important sector in comparison to the general economy and perceived lead sectors in the country. It shall further address if the tourism system is predominantly recognized from an economic point of view. To facilitate this, it is proposed to evaluate the tourism issues that parties address during nationwide elections. In case such a link exists, the outcome should display at least a connection between perceived tourism importance and tourism attention of political parties. The level of attention would provide the tourism sector with an indication of the likelihood of government support towards tourism, not only in general but specifically in case of changes in governments as a result of elections. As changes in government may result in a change in the approach to tourism (Shone and Memon, 2008), the tourism sector is required to adjust to new realities.

\section{Research on party manifestos}

Electoral processes and party positions during elections as well as party manifestos are a common subject in political science. This applies to a variety of regions and political systems. Traditionally, a tremendous amount of research is done in analysing parties' manifestos, either by expert panels or through content analytical approaches. The latter is nowadays often computer-assisted (Volkens, 2007). Research on manifestos has developed into a constant topic of interest in political science. Depending on the political system, the research on party manifestos traditionally allows a prediction about possible political actions (Hofferbert et. al., 1992). Fagan's (2018) research is supports this for politics in the U.S., at least with a short-term focus. In a European context, these short-term effects are partly backed by recent research (Borghetto et. al., 2014), with the caveat that in representative party governments the manifesto impact appears to be smaller (Froio et. al., 2017).

In the European research context, the importance of manifesto-based research is particularly demonstrated by the long-term funded 'Manifesto Project' that allows researchers around the globe 
access to manifesto data not only for Europe but other countries within the OECD for instance (Volkens et al., 2015). Overall manifesto research indicates a strong correlation between phrased political positions and policy outcomes for governing parties. This is particularly true for political positions driven by political ideologies (Bischoff, 2018).

\section{Political ideologies in tourism and leisure contexts}

Tourism as a system as well as an industry largely depends on governmental support and interaction (Jenkins, 2020, Fayos-Sola, 1996). Subsequently, political ideologies of governing parties shape their approach towards the tourism system and the tourism industry (Webster and Ivanov, 2016; Shone and Memon, 2008). As a result of this, Shone and Memon (2008) propose an equation between the change in governments with a change in ideologies resulting in a change in how tourism issues are addressed. However, this may be to a certain extent unbalanced by either a desire to retain control (Webster and Ivanov, 2016) and the predominant ideology of society with regard to leisure and tourism activities (Webster et al., 2020) or the type of governmental regime (Webster et al., 2010).

\section{Elections and tourism}

Despite the availability of manifesto data and the discussions about ideological impacts during changes of governments, tourism topics have not been in the focus of manifesto research, apart from singular instances where local politics have included specific tourism topics affecting their region (Gross and Jankowski, 2020).

However, evaluations of the interrelation between political elections and tourism are a rather common topic in research within both disciplines of tourism and politics. The relationship between tourism activities and outcomes of elections has especially already been addressed (Bachleitner \& Aschauer, 2012). Elections in general provide a temporal element important for the change of tourism policies or activities with regard to tourism development (Bowen et al., 2017; Kerr et al., 2001; Hall, 2009; Chambers \& Airey, 2001). Obviously, tourism as a phenomenon in general is prone to be affected by elections as a facilitating or blocking event. This is particularly true for political unrest followed by a disputed election (Sausmarez, 2013).

Neither of the proposed studies and papers provided an answer to the research question regarding the importance of tourism for political decision-makers. An early indication is provided by Kerr et al. (2001). The authors analysed the development of Scottish tourism policies. For those, regional elections represent an element of change and alteration (Kerr et al., 2001). On a broader scale, perspectives from Africa and Turkey provide a general impact analysis of elections on the tourism industry. Those are based on stock market positioning (Buigut \& Masinde, 2021) or a general comparison of promises made in election manifestos and the actual policies implemented after elections (Akın et al., 2019; Demirkol et al., 2016). Buigut's and Masinde's (2021) study provides some meaningful insights, but given the close link between governmental activities and tourism in developing countries (Jenkins, 2020), it does not provide an appropriate context to address the research questions. In contrast to that, Akın et al. (2019) and Demirkol et al. (2019) provide a contextual comparison, but lack a similarity in circumstances. As Turkey is largely dependent on tourism (Aslan, 2016), the topic by default receives greater attention from governments and policy-makers.

The literature review only revealed one paper that provides both meaningful insights for the research question and a comparable economic environment. Chaney (2015) analysed political party manifestos during elections in British regional parliaments to illustrate the importance of tourism as a political topic in a regional context. The study sharpens the view for the importance of analysing tourism 
awareness among political parties as it indicates tourism as an aspect in the electoral and pre-electoral competition becomes more important. Though it is proposed that tourism policies are shaped on a regional level (Chaney, 2015), the nationwide aspects need consideration as well, given the questions drawn by economic relevance and political competition could be deemed similar.

\section{Current political context and implications on general elections}

Based on the review, it would appear logical to evaluate general elections in the UK in the context of tourism awareness by political parties. But given the latest general election, like the preceding ones, was dominated by the topic 'Brexit' (Cutts et al., 2020), it appears likely that the political attention towards tourism has as well been dominated by possible Brexit effects on tourism.

Another country that might provide an answer on which to draw general conclusions is Germany. Its economy and labour market have a tourism sector similar to the UK (Eurostat, 2021) and from a socioeconomic and cultural perspective, it is perceived to have the automotive industry as a leading industry, giving the impression of a 'car country' (Haas, 2020). Looking at actual figures, the German automotive industry represented an employment opportunity for approx. 833,000 people in 2019 (Bundesministerium für Wirtschaft und Energie, 2021a), which is significantly less when compared to the almost 2,400,000 employees in Germany's tourism industry before the Covid-pandemic (Bundesministerium für Wirtschaft und Energie, 2021b). This number is not only roughly three times larger than the automotive industry's employment but also six times larger than the employment opportunities provided by the agricultural sector with approx. 600.00o employees (Deutscher Bauernverband e.V., 2021). In a nutshell, tourism is important for Germany's economy and this is contrasted by the perceived disregard of tourism matters in German politics (Jürs, 2021). However, an actual economic comparison between different industries and tourism is partly misleading as each industry is assessed differently, depending on the source of information. Tourism does not represent a traditional industry that is distinguishable to others (Brida et. al., 2008). Hence, the focus shall remain on perceptions of the industry, which also correlates to perceptions political actors might consider in their comparison of industries.

Since tourism matters affect employment opportunities of 2.4 million people in the country, it is of interest if it gets an appropriate share of attention from political parties. This would also allow an evaluation of the position of tourism in regards to general economy attention and a comparison to the car industry, as the perceived leading industry, in particular. Given German Chancellor Angela Merkel is not running for office again in the 2021 federal elections (Sauerbrey, 2021), this represents an opportunity to more clearly evaluate political preferences based on parties and their programs and ideas, instead of personality-driven incumbency advantages (Bohn, 2019) that might also be affecting the parties' manifestos.

\section{Methodology}

To address the proposed questions regarding tourism awareness, the research follows an integrated quantitative and qualitative content analysis approach (Hall, 2018) combined with elements of discourse analysis. The basis for the research is the party manifestos of political parties currently represented in the German parliament 'Bundestag', namely 'Christian Democratic Union / Christian Social Union (CDU-CSU)', 'Social Democrats (SPD)', 'Free Democrats (FDP)', 'The Left (Linke)', 'Green Party (Grüne)' and 'Alternative for Germany (AfD)'. The latter has only spent one term in the German 'Bundestag' prior to the 2021 election and is a self-proclaimed alternative to the traditional party establishment (Heinze, 2021). Defining a party establishment itself is difficult per se, given that the Green party was founded in the 1980 os (Probst, 2018) and the Left in its current form in 2007 (Neu, 2018). So, these three parties do 
not have a strong post-World War II political heritage. In addition, the manifestos of the 'Free Voters Association (Freie Wähler)' and the regional minority party 'South Schleswig Voters Association (SSW)' are included, as both associations provide manifestos for the national election and sit in the state parliaments of Bavaria and Schleswig-Holstein respectively. For those states, tourism represent an important income stream (Bayerisches Staatsministerium für Wirtschaft, Landesentwicklung und Energie, 2021; Landesportal Schleswig-Holstein, 2021). Hence, both regional parties provide a comparison opportunity regarding tourism awareness.

For clarity, it needs to be pointed out that CDU-CSU are in fact two parties that form a joint coalition party. The CSU is solely running for offices and mandates in Bavaria and the CDU solely for the remaining states of Germany (Bösch, 2018). Apart from the joint manifesto included in the evaluation, the CSU created a separate 'manifesto' primarily focusing on voters in Bavaria (CSU, 2021). This manifesto came by surprise as it was previously agreed to have only one joint manifesto (Jerabek, 2021). For this reason, as well as the limited scope with just 5.500 words (CSU, 2021) and the subsequent lack of programmatic offering, it will not be considered for the analysis proposed in this paper.

For the included manifestos, a computer-assisted quantitative content analysis was executed in a first step. Instead of a traditional coding book (Volkens, 2007, Hutter, 2020), the manifestos were auto-coded based on a three-fold coding. Within the software environment three categories have been defined:

Tourism: This category covers terms indicating a tourism context, like 'tourism' itself and also sectoral words like 'cruise', 'vacation', 'event' or, 'gastronomy', as well as related words. Those terms have been used independently as well as word-roots, word components, or lexemes to achieve the highest possible output. For robustness checks (Proksch, 2020) the sectoral words have been included in a sub-category and summed up in a separate step.

Car Industry: This category covers terms indicating a car industry context and uses terms like 'automotive industry' or 'automotive supply'. Again word-roots and lexemes have been used, where there was a term-link to the industry context. For the same reason, the stand-alone term 'car' has been excluded as it could mislead the analysis by including traffic- or environmental-related contexts and hence, overstate the occurrence.

Economy: This category covers terms indicating a general economic context like 'economy' as a standalone term or 'economic development', without focusing on individual sectors. In contrast to the other categories, no word components have been included to avoid double counting across categories.

Following the automated coding, all codes and the co-text have been reviewed to ensure terms are clearly associated with tourism or travel-related items. For the Green Party, one occurrence of a hospitality term has been removed as it is used figuratively and linked to the political situation regarding civil society in Latin America (Die Grünen, 2021). The same applies to the manifesto of the Free Voter Association, as in one instance the term 'event' was used in connection with a politician's paid participation in company events (Freie Wähler, 2021).

The occurrences of terms per category are summed up and compared against each other as well as the overall words per manifesto to evaluate the relative quantitative importance of them within the manifestos. Such an analysis is perfectly suited for computer-assisted evaluations as a significant amount of text is involved (Proksch, 2020). As Table 1 displays even the limited set of eight manifestos incorporate approx. 324,000 words. 
Table 1. Party manifestos for the general election 2021

\begin{tabular}{llll}
\hline Manifesto & Parliamentary representation & Words & Source \\
\hline AfD & Federal & 29.289 & (AfD - Alternative für Deutschland, 2021) \\
CDU-CSU & Federal (government party) & 51.034 & (CDU CSU, 2021) \\
Linke & Federal & 55.173 & (Die Linke, 2021) \\
FDP & Federal & 36.115 & (FDP, 2021) \\
Freie Wähler & State of Bavaria (government party) & 34.042 & (Freie Wähler, 2021) \\
Grüne & Federal & 70.355 & (Die Grünen, 2021) \\
SPD & Federal (government party) & 25.316 & (SPD, 2021) \\
SSW & State of Schleswig-Holstein & $\mathbf{2 2 . 6 0 8}$ & (SSW, 2021) \\
\hline Total & & $\mathbf{3 2 3 . 9 3 2}$ & \\
\hline
\end{tabular}

In order to ensure that the interpretation of the data focuses on the research questions, the paper also facilitates a qualitative contextual interpretation (Proksch, 2020). Basically, the contextual interpretation combines qualitative content analysis with context-specific elements. Those elements are shaped by the social discourse and the socio-cultural background of political campaigns and decisions (Hannam \& Knox, 2005). An important element to consider is the impact of power and interests in shaping the discourses. Each party follows their own interests when creating a manifesto. Therefore, the manifesto itself is neither neutral nor a communication measurement that exists independently of its context and the interest of its creators (Foucault, 2015). The contextual analysis therefore focuses not only on the manifestos as an intratextual dimension, but also considers intertextual as well as contextual aspects and dimensions (Rheindorf, 2017; Wodak, 2020). In this way, the analysis shall uncover relationships between the respective usage of tourism terms within the manifestos and the political context shaped by the intentions of the political parties as well as the broader social and political context (Qian et al., 2018).

In order to facilitate an analysis considering contextual dimensions, a computer-assisted co-text analysis is undertaken to evaluate the co-text of tourism or car industry related expressions extracted in step 1. This co-text spans everything from a few words to full sentences. To elaborate on the purposes of the text elements derived from the manifestos, a variety of contextual, historical, social, and political goals and contexts are considered. In essence, the co-text serves as a basis for a wider contextual analysis and interpretation incorporating the historic, social, political, and cultural environment. With this multi-level approach, the analysis of the political awareness of tourism items is neither restricted to the pure wording of political parties nor too subjective due to the researcher's degree of freedom, as the documented text is still the centre of evaluation.

\section{Results and discussion}

Quantitative content analysis

Given the large variety in the number of words of each manifesto, ranging from as low as 22.608 to as high as 70.355, focusing on absolute numbers would lead in the wrong direction. Hence, it is important to look at the numbers from a percentage and relation perspective. Table 2 provides the figures for the categories tourism, tourism sectoral, tourism total, car industry, and economy generic as a percentage of total words. The sorting is according to the political spectrum from left to right in line with the parliamentary seating order (Deutscher Bundestag, 2018; Prisner, 2018). 
Table 2. Results of the quantitative content analysis. Parties sorted from left to right of the political spectrum

\begin{tabular}{lllllll}
\hline Party & Words & \% Tourism & $\begin{array}{l}\text { \% Tourism } \\
\text { sectoral }\end{array}$ & $\begin{array}{l}\text { \% Tourism } \\
\text { total }\end{array}$ & $\begin{array}{l}\text { \% Car } \\
\text { industry }\end{array}$ & $\begin{array}{l}\text { \% Economy } \\
\text { generic }\end{array}$ \\
\hline Linke & 55.173 & $0.013 \%$ & $0.013 \%$ & $0.025 \%$ & $0.031 \%$ & $0.252 \%$ \\
Grüne & 70.355 & $0.021 \%$ & $0.007 \%$ & $0.028 \%$ & $0.023 \%$ & $0.213 \%$ \\
SPD & 25.316 & $0.012 \%$ & $0.012 \%$ & $0.024 \%$ & $0.008 \%$ & $0.225 \%$ \\
SSW & 22.608 & $0.031 \%$ & $0.004 \%$ & $0.035 \%$ & $0.000 \%$ & $0.243 \%$ \\
FDP & 36.115 & $0.036 \%$ & $0.006 \%$ & $0.042 \%$ & $0.014 \%$ & $0.274 \%$ \\
Freie Wähler & 34.042 & $0.029 \%$ & $0.009 \%$ & $0.038 \%$ & $0.009 \%$ & $0.294 \%$ \\
CDU-CSU & 51.034 & $0.029 \%$ & $0.000 \%$ & $0.029 \%$ & $0.012 \%$ & $0.233 \%$ \\
AfD & 29.289 & $0.027 \%$ & $0.000 \%$ & $0.027 \%$ & $0.027 \%$ & $0.304 \%$ \\
\hline Total & 323.932 & $0.024 \%$ & $0.006 \%$ & $0.031 \%$ & $0.018 \%$ & $0.249 \%$ \\
\hline
\end{tabular}

On a total level, the following observations can be made: Economy, in general, is a relevant topic for all parties. The manifestos address economy in general almost every 400 words. Taking the political spectrum into consideration, the economy tends to become more important from left to right. Considering a general preference for economic topics on the right-scale of the political spectrum (Gross \& Jankowski, 2020; Giebler et al., 2021), this is not surprising. Two exceptions have to be noted: 'The Left' has an above-average contribution of the economy within their manifesto, despite being the most left party analysed. This outer left position may provide a justification, as political left parties are perceived as 'opponents' of private business operations and rely on working-class issues. Hence, they are linked to economic questions more strongly as compared to moderate parties (Abou-Chadi \& Wagner, 2019). Another exception is the CDU-CSU with below-average attention to economic topics. As a governmental party, they are likely under the obligation to consider a broader variety of topics (Spoon \& Williams, 2021). The name of the manifesto document 'government program' (CDU CSU, 2021) supports this assessment.

Tourism terms are not covered with the same intensity within the manifestos. On average only 1 out of 3,200 words relates to tourism activities. It appears to have the largest impact on the manifesto of the FDP followed by SSW and Free Voters Association. One possible explanation could be drawn from their political position on the left-right spectrum and proclaiming that tourism has the biggest relevance on the centrist's parties. However, given that two out of three centrist parties are regional parties from known tourism regions, the addressing of tourism items may not only be linked to political positions. Another observation that stands out is the comparison between tourism in general and the sectoral elements. The right-wing political parties only consider generic tourism aspects, whereby left-wing parties have a strong emphasis on tourism sectors, most prominently hospitality and gastronomy. Those differences will be analysed further in the contextual analysis.

With the exception of the farthest left and the farthest right party, tourism as a phenomenon is receiving more attention than the car industry. The ratio, however, does not match the employability ratio of the industries. Only the manifestos of SPD and FDP provide an employability-compatible ratio of 3 to 1. CDU and The Greens put more emphasis on the car industry in relation to the employee ratio and the regional parties put more emphasis on tourism in reverse. Remarkably, the SSW does not address the car industry at all, despite Schleswig-Holstein having an automotive industry on a small scale (Flach \& Steininger, 2020). 


\section{Contextual Analysis}

Given the quantitative overview is comparing the perception of the tourism phenomenon with the perception of the economy in general and the automotive industry in particular, it is crucial to verify those numbers based on the contextual usage of tourism terms in the manifestos to address possible fallacies. Looking into the co-text analysis, a variety of aspects have been identified to provide a contextual perspective of the tourism-related terms. As figure 1 displays, the aspect 'economy' is the most relevant aspect addressed by the political parties in a tourism context, but on average represents only $40 \%$ of the occurrences. And the AfD with the highest amount of car industry references is not addressing tourism as an economic phenomenon at all.

\section{Covered aspects in tourism related co-text and occurences}

35

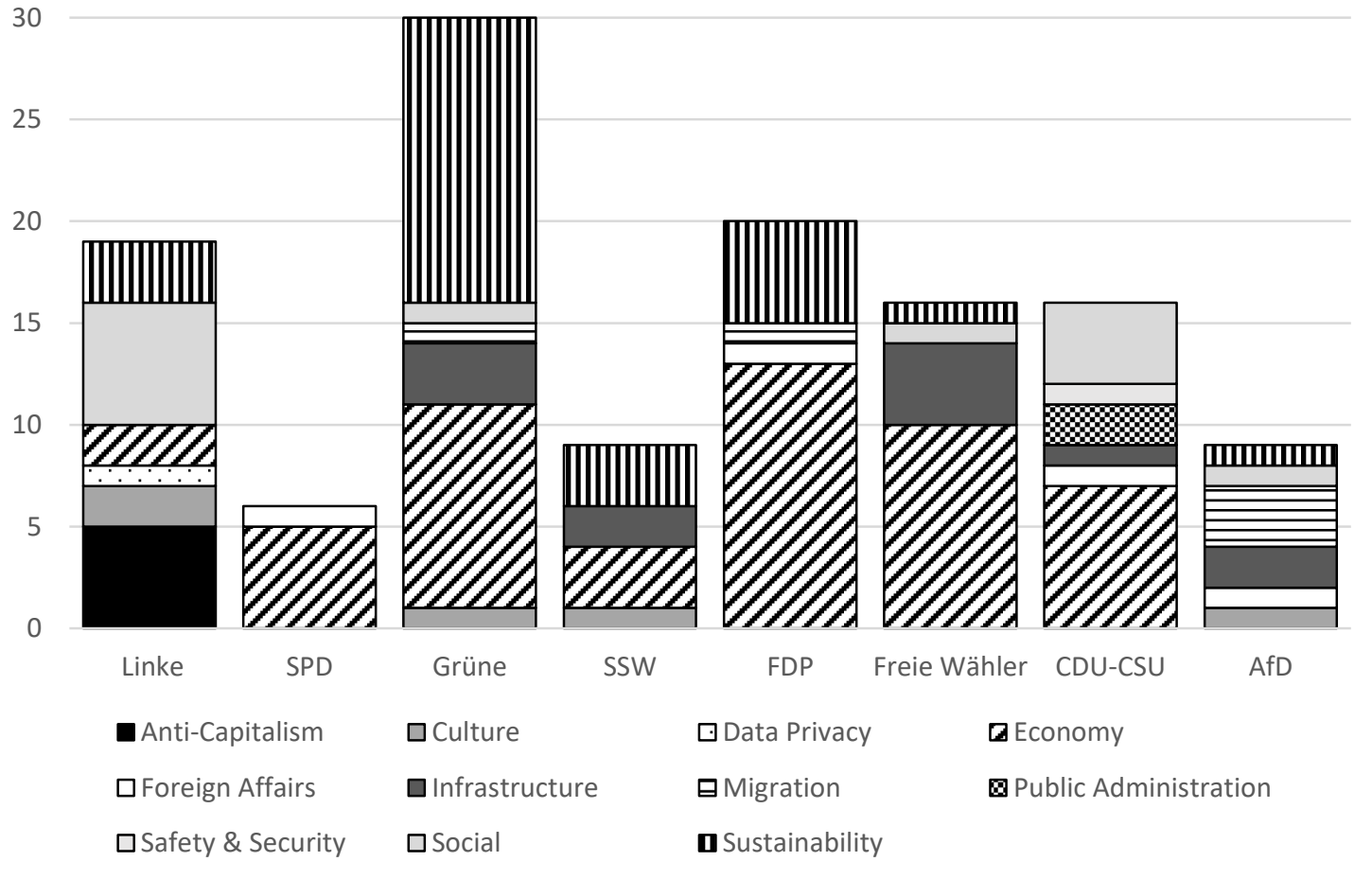

Figure 1. Aspects covered in tourism-related co-text

Following the economy, sustainability is the second most important aspect of tourism that is addressed. This also applies to the manifesto of the FDP, which most strongly emphasizes the economic aspects. Apart from those two leading aspects, social and infrastructure aspects are also pronounced by a variety of manifestos. Except for the 'Left-party', all parties represented in the federal parliament indicate a connection between tourism and foreign affairs. The absence of foreign affairs aspects in the manifestos of SSW and 'Free Voters' could be attributed to their rather regional focus on tourism. Foreign affairs are addressed in other contexts by the respective manifestos (Freie Wähler, 2021; SSW, 2021). 
The relative importance of the tourism-related aspects by party indicates a strong connection to the core issues of each party. Looking into the aspect of 'anti-capitalism' in the manifesto of 'The Left', this is almost perfectly illustrated:

Public spaces get commercialized and privatized. High-income groups and large tourism companies force large parts of the population to become background-actors in an environment directed to consumption, tourism and highest possible revenues. (Die Linke, 2021, p. 38).

Considering the historical context of the Left-party, anti-capitalism is not only part of the party's heritage (Hough et al., 2007), but also still relevant for their current political approach (Matthews \& Kerevel, 2021). The same applies to the opposite of the political spectrum, where the AfD is focusing on its core topic migration and its restriction (Trzeciak \& Schäfer, 2021).

Loss of protection status if recognized asylum seekers travel in their country of origin. Persons that visited the state of their persecutors shall be denied entry at the German border. (AfD - Alternative für Deutschland, 2021, p. 93)

It can be generalized that virtually all member parties of the federal parliament are capitalizing on tourism in proposing their core topics. The opposition parties Free Democrats focus on the economy (Höhne \& Jun, 2020) and the Green party on sustainability and environmental aspects (Probst, 2020). For the governing parties, the focus is not consistently clear. The CDU-CSU is focusing on safety and security as well as economic aspects, all of which cover their core identity (Hemmelmann, 2017). Additionally, it is the only party emphasizing the role of public administration, which may be explained with governmental responsibility (Spoon \& Williams, 2021). In contrast to that, it is surprising that the social identity of the Social Democrats (Jun, 2020) is missing the tourism context. Referring to the governmental responsibilities alone (Spoon \& Williams, 2021) does not provide sufficient reasoning as the party is only focusing on economic and foreign affairs when dealing with the tourism phenomenon. Jun (2020) proposes an explanation that can be adapted to the tourism context as well: The party has shifted the actual focus away from its traditional identity to attract new voting groups, but leaving behind traditional voter groups, especially under the government of SPD-chancellor Schröder from 1998 to 2005 .

With regard to the regional parties, it is challenging to define a coherent programmatic structure. For SSW this is somewhat plausible, given they are only present in one state of Germany. In contrast, Free Voter associations exist in several German states and municipalities. In addition, they do not have unified political objectives (Wehling \& Stortz, 2018).

Both parties have a stronger regional focus compared to traditional federal political parties (Wehling \& Stortz, 2018; Dietsche, 2018) and it appears logical that their regional focus also shapes their federal policy approach. The manifestos of SSW (2021) and Freie Wähler (2021) provide a backing for this argument, as regional aspects appear almost twice as often compared to traditional parties like the SPD (2021). Also, the tourism context provides partial backing as both regional parties have a stronger emphasis on infrastructure compared to federal parties. Infrastructure is an important element of regional development (Zhang et al., 2020; Bröcker et al., 2019) and hence this correlates with the comparable high co-textual and contextual usage in both manifestos.

We demand consideration of specific regional and touristic aspects for the reactivation of railroad tracks. (Freie Wähler 2021, p. 36) 
[Transport infrastructure] is a lifeline for tourism in the state [of Schleswig-Holstein]; in particular, local public transport is an important component. (SSW 2021, p. 43)

\section{Impact of the Covid pandemic on party manifestos}

Considering the timing of the federal elections, the pandemic may have shaped the attention towards tourism and hence impacted how political parties addressed tourism in their manifestos. Apart from singular references in the manifestos of The Greens, FDP, and Free-Voter Alliance (Die Grünen, 2021; FDP, 2021; Freie Wähler, 2021), the Covid-pandemic has not been referenced in a tourism context. So, it is fair to assume the results of the analysis indicate a general view of the political parties regarding tourism that is not influenced by a dominating external effect of a pandemic. However, it cannot be ruled out completely that the close link between sustainable tourism and the Covid-pandemic (Gössling et al., 2021; Niewiadomski, 2020; Rastegar et al., 2021; Sharma et al., 2021) impacted the perception of tourism from a voter attraction and policy needs perspective. Given the lack of clear empirical evidence for the impact of the Covid-pandemic on the parties' manifestos, it is disregarded for the purpose of the following conclusion.

\section{Conclusion and Impact on the tourism sector}

Acknowledging that the individual situation in each country has an impact on both awareness and addressing of tourism items by political parties, it is justified to assume that tourism is a phenomenon relevant for political parties on a federal or national level. According to this study, the relevance is even larger compared to the relevance of industries perceived as dominating a country's economic policy debate. This obviously is positively impacted by tourism aspects without connections to economic questions. Hence, such a comparison is not entirely justified.

Even considering other aspects and respecting the high level of awareness tourism achieves during times of elections, this awareness is biased towards each party's ideology. Political parties do not seem to consider tourism by its own merits but as a 'vehicle' to communicate their respective ideological messages. Taking this into account, it appears doubtful whether successful parties in governments chose to create and implement policies directed to the needs of the tourism system. Instead, it is more likely that the tourism policies are dominated by the respective ideological positions as well. This reflects previous studies about the changes in tourism policy due to elections (Webster \& Ivanov, 2016; Shone \& Memon, 2008).

Despite the ideological impact and its partly sobering meaning for the tourism sector, it shall by no means be argued that governments in non-tourism dominated countries tend to ignore the needs and requirements of the tourism system (as well as the tourism industry). However, the tourism sector will be forced to respond to the political positions rather than expecting a new government's policies to respond in favour of tourism to the sector's needs. In order to be successful players in tourism, as well as the respective associations, shall point out tourism's importance to achieve rather ideological goals of the governing parties. Assuming the Greens and Free Democrats will play a stronger role as an outcome of the elections (Economist, 2021), it shall be recommended not only to address economic aspects of tourism but also the sustainability dimension of tourism. This includes in particular issues where the tourism industry can support and lead sustainability efforts.

From a tourism development point of view, in particular the importance of the Greens might also lead to a stronger focus on infrastructure. Governments are pivotal in tourism development (Ruhanen, 2013; Nunkoo, 2015) and the respective infrastructure. The pivotal role of governments applies in particular 
to regional contexts (Duarte Alonso \& Nyanjom, 2017; Lamont et al., 2021). At the regional level, there is also a larger representation of tourism aspects in the parties' manifestos (Chaney, 2015) compared to the nationwide findings of this study.

Chaney's (2015) observation can partly be supported by the tourism aspects addressed in the manifestos of the SSW and the Free-Voter Alliance. However, it remains in question if such regional positions would remain prominently voiced in polices, as a federal or national government office for a regional party remains in most cases out of reach (Wehling \& Stortz, 2018). Additionally, as Spoon and Williams (2021) pointed out, even regional parties have to deal with a larger variety of areas once in a government position, resulting in a reduced focus on tourism items. For the same reason, it remains questionable if the proposed identity framing provided by tourism-related items (Chaney, 2015) will persist on a national level. Such identity frames tend only to be applied in a regional context, to differentiate the region from the state (CSU, 2021; SSW, 2021).

Also, this study could not confirm tourism as a vehicle for criticising governing parties or competing parties in general (Chaney, 2015). From a contextual perspective, the only element of 'criticism' that might be constructed on a national level is the absence of sustainability-related aspects in the manifestos of the governmental parties and the unanimously referencing of sustainability by the opposition and regional parties.

However, looking into the tourism discourse that proclaims the growing importance of sustainability and social aspects in tourism (Higgins-Desbiolles, 2020; Galvani et al., 2020; Gössling et al., 2021; Everingham \& Chassagne, 2020; Eckert \& Pechlaner, 2019; Vogler, 2021), another explanation is more compelling: Manifestos of governing parties also serve as a justification and display of success of the executed work while being in charge. Hence, a manifesto of a governing party discussing the importance of sustainability aspects in tourism could draw attention to the question of whether or not the government, and subsequently the political parties in charge, succeeded in this field.

Apart from those rather specific aspects, a general conclusion can be drawn from this study. The awareness of tourism by political parties differs significantly on a regional versus nationwide level when looking at countries with a non-tourism dominated economy. Taking Chaney's (2015) study as a reference point, it is obvious that regional elections are decided on regional matters, which include tourism. This finding is partly backed by the awareness of tourism in the two regional parties analysed. Whether or not this difference is driven by a transition to a multi-level government cannot be answered without doubt. Germany, as a federal political system, traditionally is organized in a multi-levelgovernment structure. Taking SSW and Free-Voter-Alliance as examples for governance on a different political level, it can be agreed that tourism-related policies appear to be more important at a regional level. But two aspects speak against the assumption in regards to governmental structure:

(1) The contextual analysis displayed a clear connection of tourism with specific regional themes and topics. It remains doubtful if either SSW and Free-Voters-Alliance attempt to nationalize those political ideas.

(2) In absolute referencing, virtually all parties, except AfD and SPD, put a stronger emphasis on tourism. In relative referencing, the FDP is still proclaiming more awareness towards tourism.

The same applies to the proclaimed differences in regional versus nationwide politics. This study neither backs significant differences in ideological position nor left-right orientation. However, it can be 
confirmed that both ideological foundations and left-right orientations are reflected in the awareness of tourism. This seems to apply to both regional and national levels.

Those findings and the outcome of the 2021 elections call for a variety of future research strings in tourism policy. Firstly, confirmation from other European countries is needed to be able to generalize the findings. Ideally, further research should cover a variety of political systems to evaluate differences between presidential- or parliamentary-driven systems as well as differences between centralized and federal systems. By this, parts of the German observations could be confirmed or disapproved. Taking the study of Shone and Memon (2008) as a reference, another string of research should evaluate how tourism policies in Germany change in light of the proclaimed ideological shift. Finally, as this paper suggests a different approach of the tourism sector towards the political arena and governments, it should be checked whether this is going to take place or not.

\section{References}

Abou-Chadi, T., \& Wagner, M (2019). The Electoral Appeal of Party Strategies in Postindustrial Societies: When Can the Mainstream Left Succeed? The Journal of Politics 81 (4), 1405-1419. doi: $10.1086 / 704436$.

AfD - Alternative für Deutschland (Ed.) (2021). Deutschland. Aber normal! Programm der Alternative für Deutschland für die Wahl zum 20. Deutschen Bundestag. Retrieved from: https://cdn.afd.tools/wp-content/uploads/sites/111/2021/o6/20210611_AfD_Programm_2021.pdf,.

Akın, A., Akın, A., \& Erkmen, A. (2019). Tourism Promises Expressed during Election Campaigns and the Relevant Actions Taken After the General Elections. Journal of Tourism and Gastronomy Studies 7 (2), 1414-1436. doi: 10.21325/jotags.2019.428.

Aslan, A. (2016). Does tourism cause growth? Evidence from Turkey. Current Issues in Tourism 19 (12), 1176-1184. doi: 10.1080/13683500.2015.1015970.

Bachleitner, R., \& Aschauer, W. (2012). Tourismus und EU-Wahlen. Effekte des Reisens auf die Identitätsbildung und die Wahlbeteiligung. Zeitschrift für Tourismuswissenschaft 4 (1), 57-80.

Bayerisches Staatsministerium für Wirtschaft, Landesentwicklung und Energie (2021). Tourismus: Wirtschaftsministerium Bayern. Retrieved from: https://www.stmwi.bayern.de/tourismus/.

Bischof, D. (2018). Ideological congruence between party rhetoric and policy-making. West European Politics 41 (2), 310-328. doi: 10.1080/01402382.2017.1382213.

Bohn, F. (2019). Political budget cycles, incumbency advantage, and propaganda. Econ Polit 31 (1), 4370. doi: 10.1111/ecpo.12122.

Bösch, F. (2018). Christlich Demokratische Union Deutschlands (CDU). Decker, F. and Neu, V. (Ed.). Handbuch der deutschen Parteien. Wiesbaden: Springer, 242-261.

Borghetto, E., Carammia, M., \& Zucchini, F. (2014). The Impact of Party Policy Priorities on Italian Lawmaking from the First to the Second Republic, 1983-2006. In Green-Pedersen C. and Walgrave, S. (Ed.). Agenda Setting, Policies, and Political Systems: A Comparative Approach. Chicago: University of Chicago Press, 2014, 164-182

Bowen, D., Zubair, S., \& Altinay, L. (2017). Politics and Tourism Destination Development: The Evolution of Power. Journal of Travel Research 56 (6), 725-743. doi: 10.1177/oo47287516666719.

Brida, J.G., Pereyra, J. S., \& Devesa, M. J. S. (2008). Evaluating the contribution of tourism to economic growth. Anatolia 19 (2), 351-357. doi:

Bröcker, J., Dohse, D., \& Rietveld, P. (2019). Infrastructure and regional development. In Capello, R. and Nijkamp, P. (Eds.). Handbook of regional growth and development theories. Revised and extended second edition. Cheltenham UK, Northampton MA USA: Edward Elgar Publishing, 172-197. 
Buigut, S., \& Masinde, B. (2021). The Impact of General Elections on Kenya's Tourism, Financial and Media Sector Stock Returns: An Event Study Approach. Journal of African Business, 1-19. doi: 10.1080/15228916.2021.1874793.

Bundesministerium für Wirtschaft und Energie (2021a). Automobilindustrie. BMWI. Retrieved from: https://www.bmwi.de/Redaktion/DE/Textsammlungen/Branchenfokus/Industrie/branchenfokusautomobilindustrie.html.

Bundesministerium für Wirtschaft und Energie (2021b). Tourismus. BMWI. Retrieved from: https://www.bmwi.de/Redaktion/DE/Dossier/tourismus.html.

CDU CSU (Ed.) (2021). Das Programm für Stabilität und Erneuerung. Retrieved from: https://www.csu.de/common/download/Regierungsprogramm.pdf.

Chambers, D., \& Airey, D. (2001). Tourism Policy in Jamaica: A Tale of Two Governments. Current Issues in Tourism 4 (2-4), 94-120. doi: 10.1080/13683500108667884.

Chaney, P. (2015). Exploring political parties' manifesto discourse on tourism: Analysis of Scottish, Welsh and Northern Irish elections 1998-2011. Annals of Tourism Research 50, 113-127. doi: 10.1016/j.annals.2014.11.012.

CSU (Ed.) (2021). Das CSU-Programm. Gut für Bayern. Gut für Deutschland. Retrieved from: https://www.csu.de/common/download/CSU-Programm_Gut_fuer_Bayern_Gut_fuer_ Deutschland_final.pdf.

Cutts, D., Goodwin, M. Heath, O., Surridge, P. (2020). Brexit, the 2019 General Election and the Realignment of British Politics. The Political Quarterly 91 (1), 7-23. doi: 10.1111/1467-923X.12815.

Demirkol, Ö., Solmaz, C., \& Yıldırım, M. (2016). Tourism in the electoral programs of turkish political parties: an analysis of the 2015 general elections in Turkey. International Journal of Management Economics and Business 12 (30), 81-96. doi: 10.17130/ijmeb.20163024226.

Deutscher Bauernverband e.V. - Situationsbericht - Landwirtschaft und Gesamtwirtschaft (2021). Retrieved from: https://www.bauernverband.de/situationsbericht/1-landwirtschaft-undgesamtwirtschaft-1.

Deutscher Bundestag (Ed.) (2018). 7.2 Sitzordnung im Plenum. Retrieved from: https://www.bundestag.de/resource/blob/294074/3fe82636202cf9bra6f8fd45f2b232a3/Kapitel_o7_o 2_Sitzordnung_im_Plenum-pdf-data.pdf.

Die Grünen (Ed.) (2021). Deutschland. Alles ist drin. Bundestagswahlprogramm 2021. Retrieved from: https://cms.gruene.de/uploads/documents/Wahlprogramm_DIE_GRUENEN_Bundestagswahl_202 1.pdf.

Die Linke (Ed.) (2021). Zeit zu handeln. Für soziale Sicherheit, Frieden und Klimagerechtigkeit!, Retrieved from: https://www.die-linke.de/fileadmin/download/wahlen2o21/Wahlprogramm/ DIE_LINKE_Wahlprogramm_zur_Bundestagswahl_2021.pdf.

Dietsche, H.-J. (2018). Südschleswigscher Wählerverband (SSW). Decker, F. and Neu V. (Ed.). Handbuch der deutschen Parteien. Wiesbaden: Springer, 496-505.

Duarte Alonso, A., Nyanjom, J. (2017). Local stakeholders, role and tourism development. Current Issues in Tourism 20 (5), 480-496. doi: 10.1080/13683500.2015.1078782.

Eckert, C., Pechlaner, H. (2019). Alternative Product Development as Strategy Towards Sustainability in Tourism: The Case of Lanzarote. Sustainability 11 (13), 3588. doi: 10.3390/su11133588.

Economist (2021). German Elections 2021. Retrieved from: https://www.economist.com/germanelection-2021

Elliott, J. (1997). Tourism. Politics and public sector management. London: Routledge.

Eurostat (2021). Tourism industries - employment. Retrieved from: https://ec.europa.eu/eurostat/statistics-explained/index.php?title=Tourism_industries__employment\&oldid=445425. 
Everingham, P., \& Chassagne, N. (2020). Post COVID-19 ecological and social reset: moving away from capitalist growth models towards tourism as Buen Vivir. Tourism Geographies 22 (3), 555-566. doi: 10.1080/14616688.2020.1762119.

Fagan, E. J. (2018). Marching Orders? U. Party Platforms and Legislative Agenda Setting 1948-2014. Political Research Quarterly 71 (4), 949-959.

Fayos-Sola, E. (1996). Tourism Policy: A midsummer night's dream? Tourism Management 17 (6), 405412.

FDP (2021). Nie gab es mehr zu tun. Wahlprogramm der Freien Demokraten. Retrieved from: https://www.fdp.de/sites/default/files/2021-06/FDP_Programm_Bundestagswahl2021_1.pdf.

Flach, L. \& Steininger, M. (2020). Globalisierung nach Covid-19: Die Folgen der Pandemie für die deutsche Wirtschaft. ifo Schnelldienst 73 (7), 17-23.

Foucault, M. (2015). Archäologie des Wissens. 17. Auflage. Frankfurt am Main: Suhrkamp (SuhrkampTaschenbuch Wissenschaft, 356).

Franzmann, S. T., Giebler, H., \& Poguntke, T. (2020). It's no longer the economy, stupid! Issue yield at the 2017 German federal election. West European Politics 43 (3), 610-638. doi: 10.1080/01402382.2019.1655963.

Freie Wähler (2021). Stabilität, Sicherheit, Freiheit: Die Kraft der Mitte. Retrieved from: https://www.freiewaehler.eu/template/elemente/203/FREIE\%20W\%C3\%84HLER_Wahlprogramm -BTW21.pdf.

Froio, C., Bevan, S., \& Jennings, W. (2017). Party mandates and the politics of attention: Party platforms, public priorities and the policy agenda in Britain

Galvani, A., Lew, A. A., \& Perez, M. S. (2020). COVID-19 is expanding global consciousness and the sustainability of travel and tourism. Tourism Geographies 22 (3), 567-576. doi: 10.1080/14616688.2020.1760924.

Giebler, H., Meyer, T. M., \& Wagner, M. (2021). The changing meaning of left and right: supply- and demand-side effects on the perception of party positions. Journal of Elections, Public Opinion and Parties 31 (2), 243-262.

Gössling, S., Scott, D., \& Hall, C. M. (2021). Pandemics, tourism and global change: a rapid assessment of COVID-19. Journal of Sustainable Tourism 29 (1), 1-20. doi: 10.1080/09669582.2020.1758708.

Gross, M., \& Jankowski, M. (2020). Dimensions of political conflict and party positions in multi-level democracies: evidence from the Local Manifesto Project. West European Politics 43 (1), 74-101.

Haas, T. (2020). From Green Energy to the Green Car State? The Political Economy of Ecological Modernisation in Germany. New Political Economy, 1-14. doi: 10.108o/13563467.2020.1816949.

Hall, C. M. (2009). Innovation and tourism policy in Australia and New Zealand: never the twain shall meet? Journal of Policy Research in Tourism, Leisure and Events 1 (1), 2-18. doi: 10.1080/19407960802703466.

Hall, C. M. (2018). Quantitative and qualitative content analysis. Robin Nunkoo (Ed.). Handbook of research methods for tourism and hospitality management. Cheltenham, UK, Northampton, MA, USA: Edward Elgar Publishing (Handbooks of research methods in management), 395-406.

Hannam, K., \& Knox, D. (2005). Discourse Analysis in Tourism Research A Critical Perspective. Tourism Recreation Research 30 (2), 23-30. doi: 10.1080/02508281.2005.11081470.

Heinze, A. (2021). Zum schwierigen Umgang mit der AfD in den Parlamenten: Arbeitsweise, Reaktionen, Effekte. Zeitschrift für Politikwissenschaft 31, 133-15o. doi: 10.1007/s41358-020-00245-0.

Hemmelmann, P. (2017). Der Kompass der CDU. Wiesbaden: Springer.

Higgins-Desbiolles, F. (2020). Socialising tourism for social and ecological justice after COVID-19. Tourism Geographies 22 (3), 610-623. doi: 10.1080/14616688.2020.1757748.

Hieu, V.M. \& Yen, H.T.B. (2019). Analysing economic contribution of tourism: insights from selected Southeast Asian countries. Management 23 (2), 223-237 
Höhne, B., \& Jun, U. (2020). Die FDP zwischen Wahlerfolgen, Regierungsflucht und Stagnation. Jun, U. and Niedermayer, O. (Ed.). Die Parteien nach der Bundestagswahl 2017. Wiesbaden: Springer, 133157.

Hofferbert, R., Klingemann, H.-D., \& Volkens, A. (1992). Wahlprogramme, Regierungserklärungen und Politisches Handeln Zur »Programmatik politischer Parteien«. In Andreß, H.J. (Ed.). Theorie, Daten, Methoden. München: Oldenbourg, 383-392.

Hough, D., Koss, M., \& Olsen, J. (2007). The Left Party in contemporary German politics. Basingstoke: Palgrave Macmillan

Hutter, S. (2020). Quantitative Inhaltsanalyse. In Wagemann, C., Goerres, A., Siewert, M.B. (Ed.). Handbuch Methoden der Politikwissenschaft. Wiesbaden: Springer, 837-859.

Jenkins, C. L. (2020). The role of government in the tourism sector in developing countries: a perspective article. Tourism Review 75 (1), 203-206. doi: 10.1108/TR-04-2019-0142.

Jerabek, P. (2021). Wahlprogramm der CSU: Söders doppelte Warnung. Retrieved from: https://www.tagesschau.de/inland/btw21/csuprogramm-101.html.

Jun, U. (2020). Die Krise der SPD: Kaum Licht am Ende des Tunnels. In Jun, U. and Niedermayer, O. (Ed.). Die Parteien nach der Bundestagswahl 2017. Wiesbaden: Springer, 71-104.

Jürs, M. (2021). Tourismuspolitik bleibt Baustelle. fvw - TravelTalk, 28.05.2021 (11), 22-23.

Kerr, B., Barron, G., \& Wood, R. C. (2001). Politics, policy and regional tourism administration: a case examination of Scottish area tourist board funding. Tourism Management 22 (6), 649-657. doi: 10.1016/So261-5177(01)00038-3.

Lamont, M., Scherrer, P., \& Dimmock, K. (2021). Participant-governed networks as catalysts for sustainable transport and tourism infrastructure: the Northern Rivers Rail Trail, Australia. Tourism Recreation Research, 1-16. doi: 10.1080/02508281.2021.1934332.

Landesportal Schleswig-Holstein (2021). Tourismus - Urlaubsland Schleswig-Holstein. Retrieved from: https://www.schleswig-holstein.de/DE/Landesregierung/Themen/Wirtschaft/Tourismus/ tourismus_node.html.

Matthews, A. S., \& Kerevel, Y. P. (2021). The Nomination and Electoral Competitiveness of Working Class Candidates in Germany. German Politics, 1-17. doi: 10.1080/o9644008.2021.1874935.

Mattioli, G., Roberts, C., Steinberger, J. K., \& Brown, A. (2020). The political economy of car dependence: A systems of provision approach. Energy Research $\mathcal{E}$ Social Science 66, 101486. doi: 10.1016/j.erss.2020.101486.

Neu, V. (2018). Die Linke (DIE LINKE). In Decker, F. and Neu, V. (Ed.). Handbuch der deutschen Parteien. Wiesbaden: Springer, 384-401.

Niewiadomski, P. (2020). COVID-19: from temporary de-globalisation to a re-discovery of tourism? Tourism Geographies 22 (3), 651-656. doi: 10.108o/14616688.2020.1757749.

Nunkoo, R. (2015). Tourism development and trust in local government. Tourism Management 46, 623634. doi: 10.1016/j.tourman.2014.08.016.

Perles-Ribes, J. F., Ramón-Rodríguez, A. B., Sevilla-Jiménez, M., \& Moreno-Izquierdo, L. (2016). Unemployment effects of economic crises on hotel and residential tourism destinations: The case of Spain. Tourism management, 54, 356-368.

Prisner, E. (2018). An Attempt to Position the German Political Parties on a Tree for 2013 and 2017. Statistics, Politics and Policy 9 (1), 31-56. doi: 10.1515/spp-2018-0oo1.

Probst, L. (2018). Bündnis 9o/Die Grünen (GRÜNE). In Decker, F. and Neu, V. (Ed.). Handbuch der deutschen Parteien. Wiesbaden: Springer, 203-218.

Probst, L. (2020). Bündnis 9o/Die Grünen: Grüne Erfolgswelle nach enttäuschendem Wahlergebnis. In Jun, U. and Niedermayer, O. (Ed.). Die Parteien nach der Bundestagswahl 2017. Wiesbaden: Springer, 187-219. 
Proksch, S.-O. (2020). Computergestützte Textanalysen. In Wagemann, C., Goerres, A., Siewert, M.B (Ed.). Handbuch Methoden der Politikwissenschaft. Wiesbaden: Springer, 817-835.

Qian, J., Wei, J., \& Law, R. (2018). Review of critical discourse analysis in tourism studies. International Journal of Tourism Research 20 (4), 526-537. doi: 10.1002/jtr.2202.

Rastegar, Ra., Higgins-Desbiolles, F., \& Ruhanen, L. (2021). COVID-19 and a justice framework to guide tourism recovery. Annals of Tourism Research, 103161. doi: 10.1016/j.annals.2021.103161.

Rheindorf, M. (2017). Integration durch Strafe? Die Normalisierung paternalistischer Diskursfiguren zur »Integrationsunwilligkeit«. Zeitschrift für Diskursforschung - Journal for Discourse Studies 5 (2), 182206.

Ruhanen, L. (2013). Local government: facilitator or inhibitor of sustainable tourism development? Journal of Sustainable Tourism 21 (1), 80-98. doi: 10.1080/o9669582.2012.680463.

Sauerbrey, A. (2021). Opinion | The Race to Replace Angela Merkel Is On. The New York Times, 26.04.2021. Retrieved from: https://www.nytimes.com/2021/o4/26/opinion/merkel-laschetbaerbock.html.

Sausmarez, N. (2013). Challenges to Kenyan tourism since 2008: crisis management from the Kenyan tour operator perspective. Current Issues in Tourism 16 (7-8), 792-809. doi: 10.1080/13683500.2013.785488.

Sharma, G. D., Thomas, A., \& Paul, J. (2021). Reviving tourism industry post-COVID-19: A resiliencebased framework. Tourism Management Perspectives 37, 100786. doi: 10.1016/j.tmp.2020.100786.

Shone, M.C., \& Memon, P.A. (2008). Tourism, Public Policy and Regional Development: A Turn from Neo-liberalism to the New Regionalism. Local Economy 23 (4), 290-304

SPD (2021). Aus Respekt vor deiner Zukunft. Zukunftsprogramm der SPD. Retrieved from: https://www.spd.de/fileadmin/Dokumente/Beschluesse/Programm/SPD-Zukunftsprogramm.pdf.

Spoon, J.-J., \& Williams, C. J. (2021). 'It's the economy, stupid': when new politics parties take on old politics issues. West European Politics 44 (4), 802-824.

SSW (2021). SSW - Deine Stimme für Schleswig-Holstein. Retrieved from: https://www.ssw.de/fileadmin/user_upload/Bundestagswahlprogramm_2021-08.05.21.pdf.

Trzeciak, M. F., \& Schäfer, J. (2021). “Aggressive Refugees, Violent Hooligans, Concerned Citizens”: Reinterpreting Multiple Processes of Difference-Making in Mediatizations of Migration and Conflict in East Germany in the German Media 1. Journal of Immigrant E Refugee Studies 19 (1), 55-67. doi: 10.1080/15562948.2020.1856995.

UNWTO (2018). European Union Tourism Trends. doi: 10.18111/9789284419470.

Vogler, R. (2021). Revenge and catch-up travel or degrowth? Debating tourism Post COVID-19. Annals of Tourism Research, 103272. doi: 10.1016/j.annals.2021.103272.

Volkens, A. (2007). Strengths and weaknesses of approaches to measuring policy positions of parties. Electoral Studies 26, 108-120. doi: 10.1016/j.electstud.2006.04.00

Volkens, A., Ares, C., Bratanova, R., \& Kaftan, L. (2015). Scope, Range, and Extent of Manifesto Project Data Usage: A New Research Tool for Manifesto Project Database's Users. RIP Revista de Investigaciones Políticas y Sociológicas, 14 (2), 217-232

Webster, C., Ivanov, S. \& Illum, S. F. (2011) The paradigms of political economy and tourism policy: National tourism organizations and state policy. In Mosedale, J. (ed.) Political economy of tourism. A critical perspective. London: Routledge, pp. 55-73.

Webster, C. and Ivanov, S. (2016). Political ideologies as shapers of future tourism development. Journal of Tourism Futures 2 (2), 109-124. Doi: 10.1108/JTF-05-2015-0029

Webster, C., Yen, C.-L. \& Hji-Avgoustis, S. (2020). Individual Perceptions of the Value of Leisure: The Influence of the Social Democratic Welfare State and Leftist Values Systems. European Journal of Tourism Research 24, 2402 
Wehling, H.-G., Stortz, O. (2018). Freie Wähler (FREIE WÄHLER). In Decker, F. and Neu, V. (Ed.). Handbuch der deutschen Parteien. Wiesbaden: Springer, 333-340.

Wodak, R. (2020). Diskursanalyse. In Wagemann, C., Goerres, A., Siewert, M.B. (Ed.). Handbuch Methoden der Politikwissenschaft. Wiesbaden: Springer, 881-902.

Zhang, J., Zhang, D., Li, L., \& Zeng, H. (2020). Regional impact and spillover effect of public infrastructure investment: An empirical study in the Yangtze River Delta, China. Growth and Change 51 (4), 1749-1765. doi: 10.1111/grow.12427.

Received: 14/o9/2021

Accepted: 11/11/2021

Coordinating editor: Stanislav Ivanov 